\title{
脳・脊䯣血管撮影の歴史と立体視の有用性
}

\author{
小宮山雅樹
}

\section{History of angiography of the cerebral and spinal vessels and the importance of stereoscopic viewing}

\author{
Masaki KOMIYAMA \\ Department of Neuro-Intervention, Osaka City General Hospital \\ Abstract
}

\begin{abstract}
Interpretation of a detailed vascular anatomy is essential for safe and secure, surgical and/or interventional treatments of the vascular diseases of the central nervous system. To obtain such anatomical data, modern CT/MR imaging is less invasive and has become the primary diagnostic modality today. Catheter angiography has an inherent risk of various complications, but still remains useful diagnostic modality in many situations. The author has reviewed the role of stereoscopic viewing of the vascular images of the central nervous system, especially digital subtraction angiograms, as well as three-dimensional angiograms reconstructed by CT/MR imaging.
\end{abstract}

\section{Key words}

cerebral angiography, digital subtraction angiography, spinal angiography, stereoscopic angiography

大阪市立総合医療センター 脳血管内治療科

<連絡先：干 534-0021 大阪市都島区都島本通 2-13-22 E-mail: komiyama@japan-mail.com >

(Received January 6, 2015 : Accepted January 19, 2015)

\section{はじめに}

脳・脊髄の血管の解剖を見るためには, カテーテ ル血管撮影が必須であった時期を過ぎ，今では低侵 襲な CT/MRによる血管画像でその解剖が概ね分かる ようになってきた。しかし，最新の CT/MRを使っ た診断法でも解剖学的な理解が難しい場合も少なく ない.また血管内治療の施行時には, 血管撮影は必 須であるし，春髄の血管病変には未だ重要な診断手 段であり gold standardでもある。筆者は, 銀フィル ムを使用したカテーテル血管撮影の時期から(filmscreen angiography), 手作業で subtractionしていた時 期(film subtraction), ついで image intensifier 利用 したDSA (digital subtraction angiography)の黎明期か

ら flat panel detectorを利用したDSAに変わり, 3D rotation angiography やCT-like image の撮像が可能に なった時期を経験してきた。この間にフィルム上の
画像デー夕を読影する時期から, filmless となり, 種々の画像データをモニター上で観察する時代に変 わっていった. CT/MR angiography の活用が進み, 次 第に立体撮影 (stereoscopic imaging)の血管撮影像を見 る機会が減っていった。しかし現在のように進歩し た種々の脳・春髄血管の画像診断法がある中にあっ ても，1980 年代からよく行なわれていた立体撮影に よる脳・春髄血管撮影は未だ色裉せず，重要で有用 な診断方法であるという観点から，その脳・脊髄血 管撮影法のレビューを行なった。

\section{脳血管撮影法の歴史}

画像診断は, 1895 年の Wilhelm Conrad Röentgen （1845-1923）によるx-rayの発見から始ったと言え る ${ }^{1)}$. x-ray が発見されたというニュースは瞬く間に世 界中に伝えられ，翌年には臨床応用への模索が始ま る。しかし，現実的には，1910年ごろまで単純撮影 
による骨折や異物の検出がその主な使用方法である時 期が長く続いた。脳病変の局在診断への利用は, 単純 撮影上の石灰化病変の検出や松果体の変位などの読 影で行われた。この頃, 頭部外傷による気脳症で脳室 に入った空気が観察されていた。その空気という造影 剂による脳室造影 pneumoventriculography や脳表面造 影 pneumoencephalography が 20 世紀に入り行われる ようになる. Walter Dandy(1886-1946)は 1918 年に脳 室造影の報告をしている2)。しかし, 脳病変の局在診 断は間接所見が主であった ${ }^{3)}$ 。そのころ油性の造影剂 である Lipiodol ${ }^{\circledR}$ を使った脊髄造影が，1921 年にフラ ンスの Sicard と Forestierにより始まる゙． Lipiodol ${ }^{\circledR}$ 自 身は，1901 年に開発されている。血管撮影に使用守 る種々の造影剤が動物実験で試みられるが，毒性が 強く合併症も多かったことから，なかなか実用化され ず，従って血管撮影も広まらなかった ${ }^{5)}$. ヒトの生体 血管撮影は，1923 年に Berberich と Hirsch が $20 \%$ 臭 化ストロンチウムの造影剤を使い四肢の動脈及び静脈 造影に成功している6

ポルトガルの神経学者の Egas Moniz(1874-1955) は, 当時, 脳腫瘍の局在診断の唯一の方法であった が, 必ずしも安全で有効とも言えない脳室造影に 代わる診断方法を模索していた。そして 1927 年に $25 \%$ ヨウ化ナトリウムの造影剤を使い, 最初の脳血 管撮影を鞍部腫瘍の症例で成功させた は, ヒト生体に血管撮影を行う前に, 屍体で立体撮 影を行い，その有用性について言及している2)。国内 では名古屋大学の齋藤 眞 $(1889-1950)$ らが Lipiodol ${ }^{\circledR}$ を基にした乳濁液の造影剤 L'ombre ロンブル (ombre はフランス語で影の意味）を開発し, 1930 年に arterial encephalography と呼び脳血管撮影を報告し た5)。彼らは, この早期の時点で立体撮影も行ってい た。その後は、より安全な造影剤の開発が続いた。 血管の穿刺法として Moniz の頃から経皮的穿刺法が あったが, 成功率が低いため, 頚動脈や椎骨動脈を 直接外科的に露出してから動脈を穿刺し造影剂を注 入する手技が長く行われた。この頃は，近位動脈を 血管クランプなどで一時的に閉塞した状態で，露出 された動脈を穿刺して撮影を行っており，血流が流 れた状態の動脈撮影ではなかった。一方，1936年に Boston の Loman と Myerson $ら^{8)}$ が経皮的な総澒動脈 穿刺による䅡動脈撮影を行なった。その背景には精 神疾患の治療として薬物を頚動脈に直接注入する手
技が行われていたことがある。この頃の脳血管撮影 は主に頭部側面像の 1 枚撮りであった。これは当時 の x-ray 撮影装置の性能と感光材料では前後方向の短 時間撮影を行うことは困難であったからも推察され る。翌 1937 年に Shimidzu も同様の手技で頚動脈撮 影を行っているが9)，この手技は 1940 年代半ばまで あまり普及はしなかった。

椎骨動脈撮影は，1933 年にはMonizらにより鎖 骨下動脈を露出して穿刺による造影がされるように なり，その後，1940年には Takahashiにより経皮的 に椎骨動脈を穿刺して造影が行われた ${ }^{10)}$. しかし手 技が煩雑であるため，それに代わる経皮的な逆行性 上腕動脈造影が一般化していく.1953 年に発表さ れた Sven-Ivar Seldinger(1921-1998）による「経皮的 動脈造影法で針をカテーテルに取り替える新方法」 により, カテーテル脳血管撮影が画期的に進歩し た ${ }^{11)}$ 。この手技は，国内では 1970 年代に入り徐々 に普及していく，現実には 1980 年代前半まで，右 側上腕動脈からの逆行性の血管撮影と左側の䅡部総 頚動脈を $18 \mathrm{G}$ のエラスター針で経皮的に直接穿刺す る脳血管撮影が多くの施設で行われていた。画像化 の媒体は，長く銀フィルムであり (conventional filmscreen angiography)，これを使った撮影方法の種々の 工夫がおこなわれていた，2方向(正面・側面)同時 撮影, 連続撮影(高速にフィルムを入れ替える film cassette exchangerが開発された), 拡大撮影(高容量 の x-ray 発生装置が開発された), 断層撮影(angiotomography), フィルムを使った subtraction 法, さら に本稿で強調したい立体撮影 stereoscopic angiography が行われるようになり ${ }^{12,13)}, \mathrm{CT} / \mathrm{MR} の$ 技術革新とと もに，脳血管の評価がより精密になっていった。一 方，1960 年代後半には, Salamon や Huang らにより ヒトの屍体の脳血管に造影剤を注入後に立体撮影を 行い脳動脈や脳静脈の詳細な構築について報告がな された ${ }^{14)}$.

1980 年代に入り，徐々にDSA が普及するが，当 初, 頭蓋外の閉塞性血管病変や術後の脳血管撮影や 外来レベルでのスクリーニングの脳血管撮影が目的 であった。その手技は肘静脈に置いた $16 \mathrm{G}$ のエラス ター針や肘静脈から挿入し上大静脈や無名静脈にそ の先端を置いた 5 French の pig-tail カテーテルから の静脈内への造影剤注入によるDSA が行なわれて いた(静注 DSA $)^{15,16)}$ 。しかし，脳血管撮影の主役は 
大腿動脈から挿入したカテーテルを用いた動脈造影 film-screen angiographyであった。このころは, CT angiography や MR angiography の出現前であり, 無症 候性の病変の検查に侵襲のあるカテーテル血管撮影 に代わる静注 DSA に期待が寄せられていたが, 静注 DSA は，患者の動き，多くの血管の重なり，造影剂 の量が多いこと, 解像度が高くないことなどから, 広く普及するに至らなかった。それに代わりDSAの 目的が次第に, 現在の大腿動脈からのアプローチに よる動脈造影(動注 DSA)に変わっていき, 頭蓋内の 病変にも使われるようになっていった ${ }^{17)}$. 動注 DSA には, 造影剤量の減少, 選択的造影の必要性の低下 (内頝動脈撮影ではなく総澒動脈撮影でも解像度の高 い画像が得られるため), フィルムのコスト低下 (大 きな cut film の使用の必要がなく, また枚数も減らせ る), 検查時間の短縮(フィルムの場合には現像に時 間がかかる), road map の使用が可能, より細い動脈 の認識が可能などの利点があった. 1980 年代の後半 から 1990 年代には, フィルムによる撮影法が衰退し て, やがて画像データをモニター上に表示される読 影法に変わっていく，それに伴い画像データの保存 もサーバーに置かれるようになる，頭部全体が撮影 される film-screen angiography が当初好まれ, 撮像領 域の狭い動注 DSA は，脳神経外科医の一部に敬遠さ れたこともあったが，その有用性が広く受け入れら れていく. DSAであっても次第に撮像可能な範囲も 大きくなり，この動注 DSA が広まっていく ${ }^{18,19)}$ 。散 乱線の問題で, 2 方向(正面像と側面像)の同時撮影 (simultaneous biplane angiography) は，当初できなかっ たが，次第に 2 方向の同時撮影が一般的になってい く ${ }^{13)}$ ，21 世紀に入り CT/MRによる脳血管の評価が 可能な CT angiography や MR angiography が臨床で使 用されるようになり，カテーテル脳血管撮影の施行 頻度が下がり, より限られた症例で行われるように なっていった。

\section{脊㖪血管撮影法の歴史}

選択的脊髄動脈撮影は, 歴史的に見て Di Chiro G, Doppman JL，Djindjian R らの業績が大きい20-22)，1970 年代には, 欧米でも対麻痺や下肢の痤攣などの合併 症に対する危惧があり，一般化するには時間がかっ た，脊髄動脈撮影が一般化していった背景には，安 全性の高い非イオン性の造影剤の開発が大きく，技
術的にはDSAの進歩，さらに診断用のカテーテルの 進歩に加え, 治療用のマイクロカテーテルやガイド ワイヤーの開発も大きな役割を果たした。今でも, 春䯣の血管病変の診断・治療には, 脊髄の選択的 血管撮影は gold standard である ${ }^{23)}$ 。血管構築は単純 な春髄の血管であるが，その細さ，血流の少なさか ら，血管撮影には種々の工夫が必要とされ，体動を 抑える全身麻酔や腸管の動きを抑える薬剤を利用す る。また各分節動脈撮影を正面像で行い，神経根髄 質動脈や神経根軟膜動脈などを分岐する重要な分節 動脈は，立体撮影や側面像も加えた 2 方向からの撮 影が行なわれるようになった。

\section{立体撮影法と立体視}

2 枚のフィルムで立体視 (stereoscopic viewing)する ことは，単純撮影が可能になった 20 世紀に入ってす ぐの頃から一般的に行われていたが，連続撮影が必 要な血管撮影の立体撮影は, 早期からアイデアはあ るものの, 臨床応用が始まるのは 1960 年代に入って からであった。連続撮影でない 1 枚撮りの立体血管 撮影は，前述のように1930 年にすでに齋藤らによ り行われていた ${ }^{5)}$. 2 回の撮影で立体画像にすること は可能であったが，造影剤を 2 回注入することに抵 抗があり, 一回の注入で立体連続撮影を行う方法が 模索される。1 回の連続撮影で立体撮影をするため 1 管球を短時間に 2 つ位置の間を何度も行き来さ

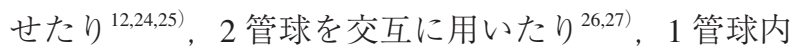
に 2 焦点を持つ管球 (dual-focus x-ray tube)を用いたり された ${ }^{28)}$ そそのため正面と側面の 2 方向での立体画 像ではなく，正面画像は，通常の非立体撮影で，側 面画像だけ立体撮影をする時期が続く ${ }^{12,13)}$ ，立体撮影 用の x-ray 線管球は海外では生産されないようになっ ても，日本の脳神経外科医や神経放射線科医には好 まれていたため, 国内メーカーでは生産されていた が，それも徐々に生産されなくなった。その後，脳・ 春髄は他の消化管や肺・肝臓などの臓器と異なり 大きな動きがないため, 1 焦点を持つ 1 管球 (singlefocus x-ray tube）を用い一定の角度をずらして同じ連 続撮影を 2 回する方法がとられていく。臨床の場 で，脳血管撮影に立体撮影が使われるようになった のは 1980 年代に入った頃からであった。

単純撮影でも血管撮影でも立体視をするための撮 像は，一定の角度 (convergent angle)を 6〜12 度ずら 

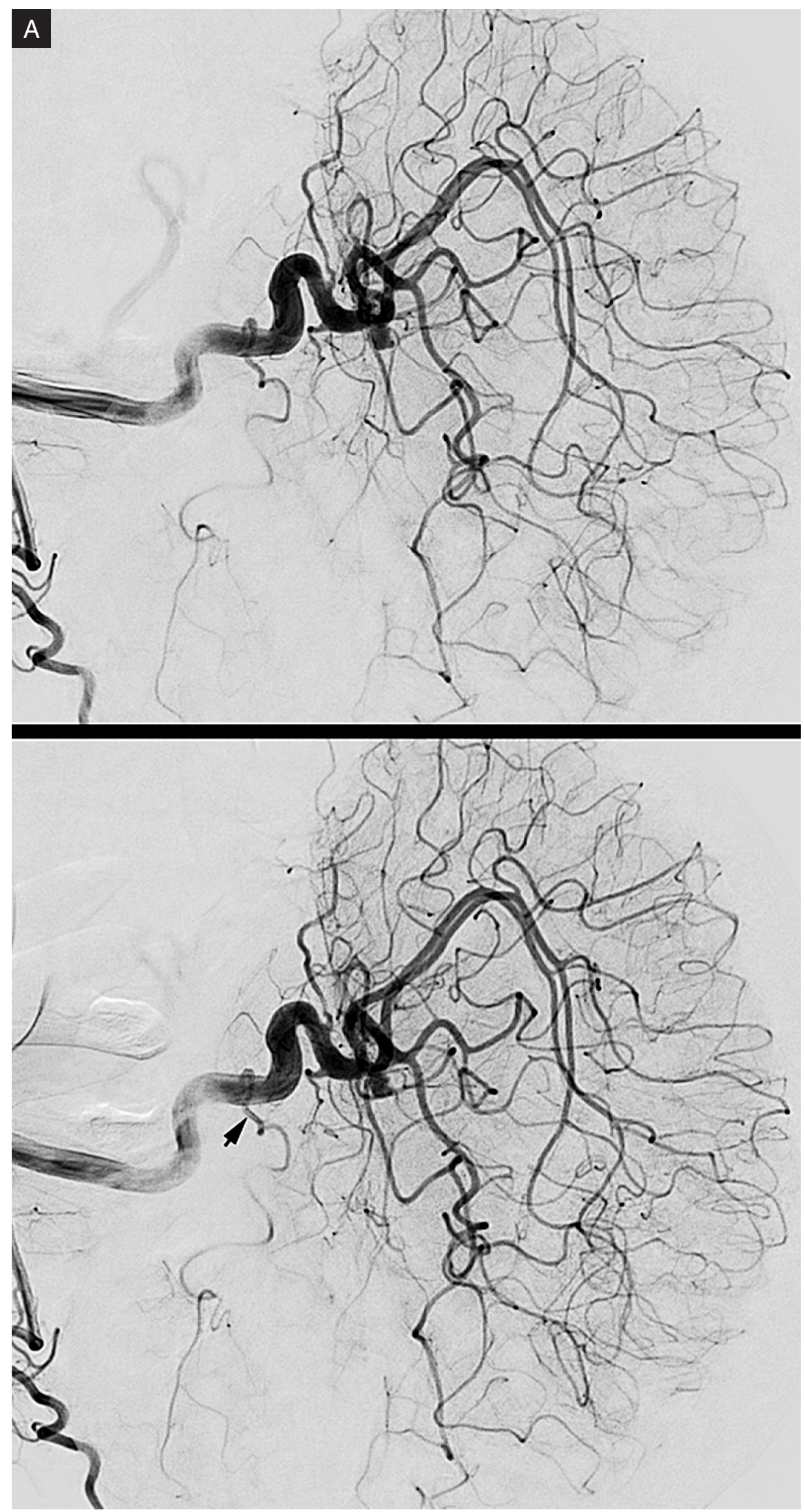

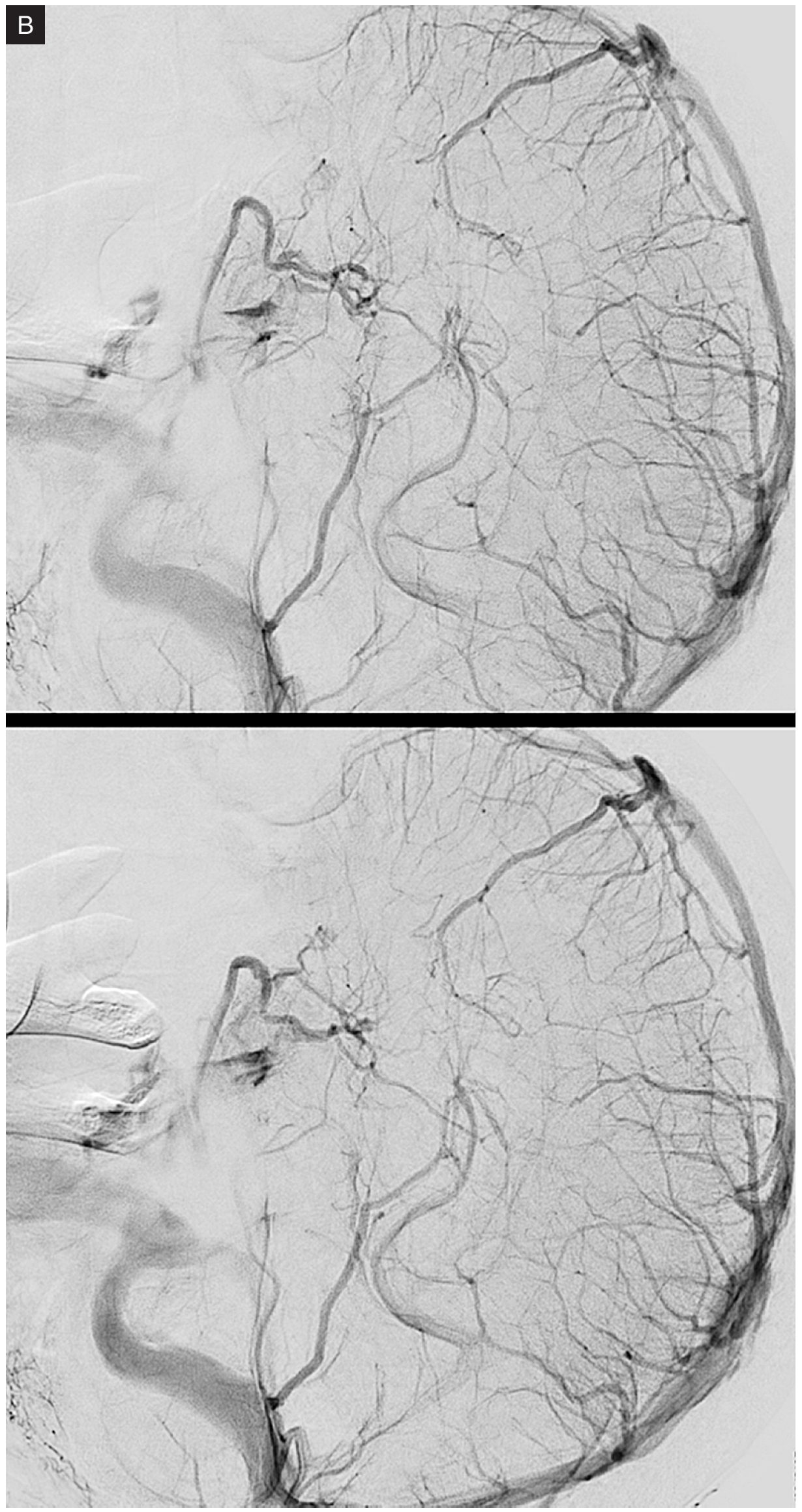

Fig. 1

A 54-year-old woman with an incidentally discovered saccular aneurysm at the top of the left internal carotid artery. Stereoscopic left internal carotid angiograms (lateral views).

A: Arterial phase. Interpretation of the detailed anatomy of the proximal M2 branches (trifurcation) confidently is not possible by overlapping of the vessels with non-stereoscopic single lateral angiogram. Stereoscopic viewing enables 3-dimensional interpretation of these vessels. Arrow indicates a trigeminal artery variant.

B: Venous phase. Less familiar venous anatomy, for example, septal vein, anterior caudate vein, thalamostriate vein, and inferior sagittal sinus, is readily identifiable with stereoscopic viewing. Left superficial middle cerebral vein is hypoplastic. 


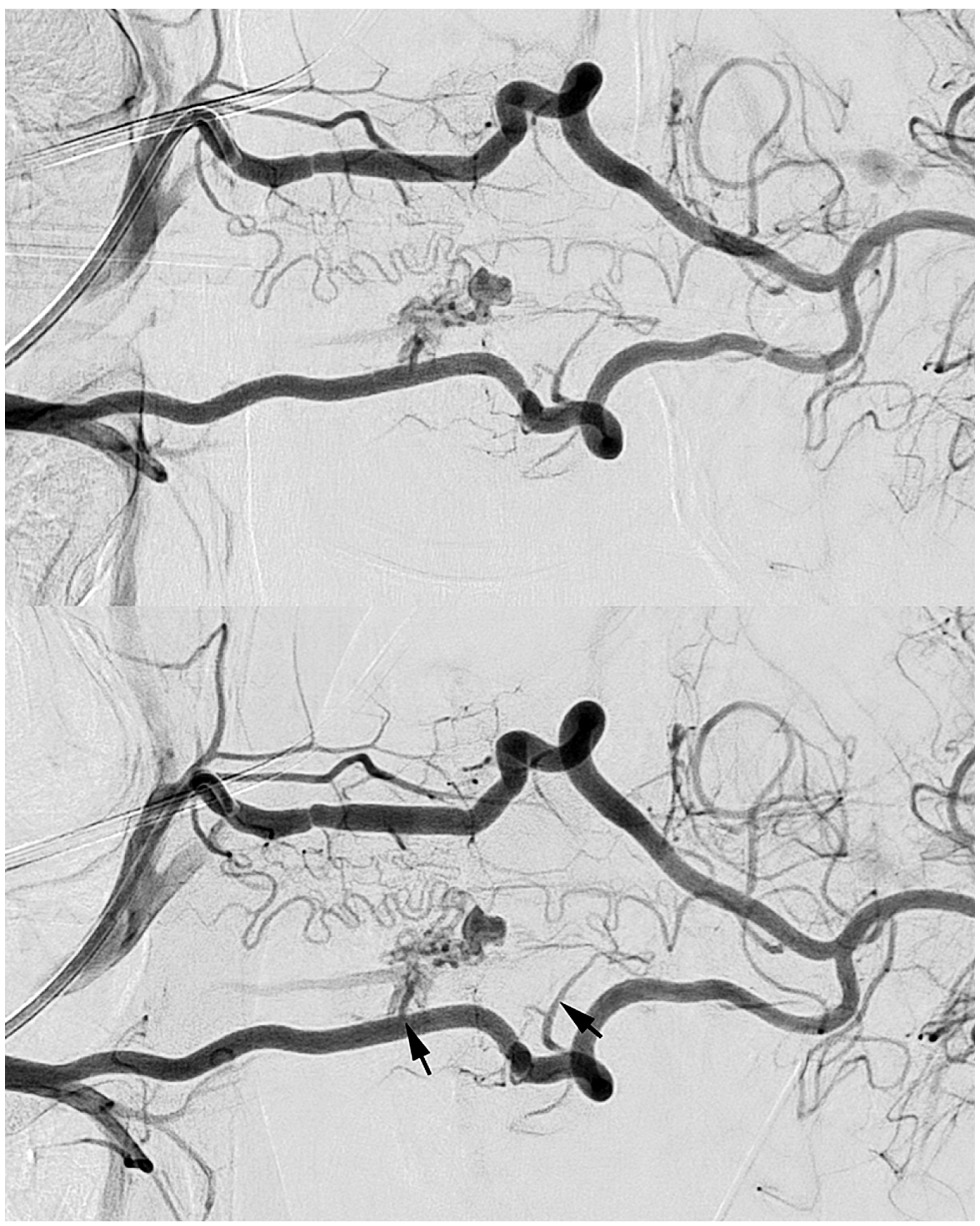

Fig. 2

A neonatal girl with a hemorrhagic spinal arteriovenous fistula (AVF). Right vertebral stereoscopic angiograms (AP views) show an AVF mainly fed by the left C2 and C4 segmental arteries (arrows). Accompanying small varix is also demonstrated. Anterior spinal artery, branching off from the V4 portion and the proximal V2 portion (C7 segmental artery) of the right vertebral artery, is less contributory to the AVF. Stereoscopic viewing facilitates the interpretation of the detailed anatomy of the AVF. 

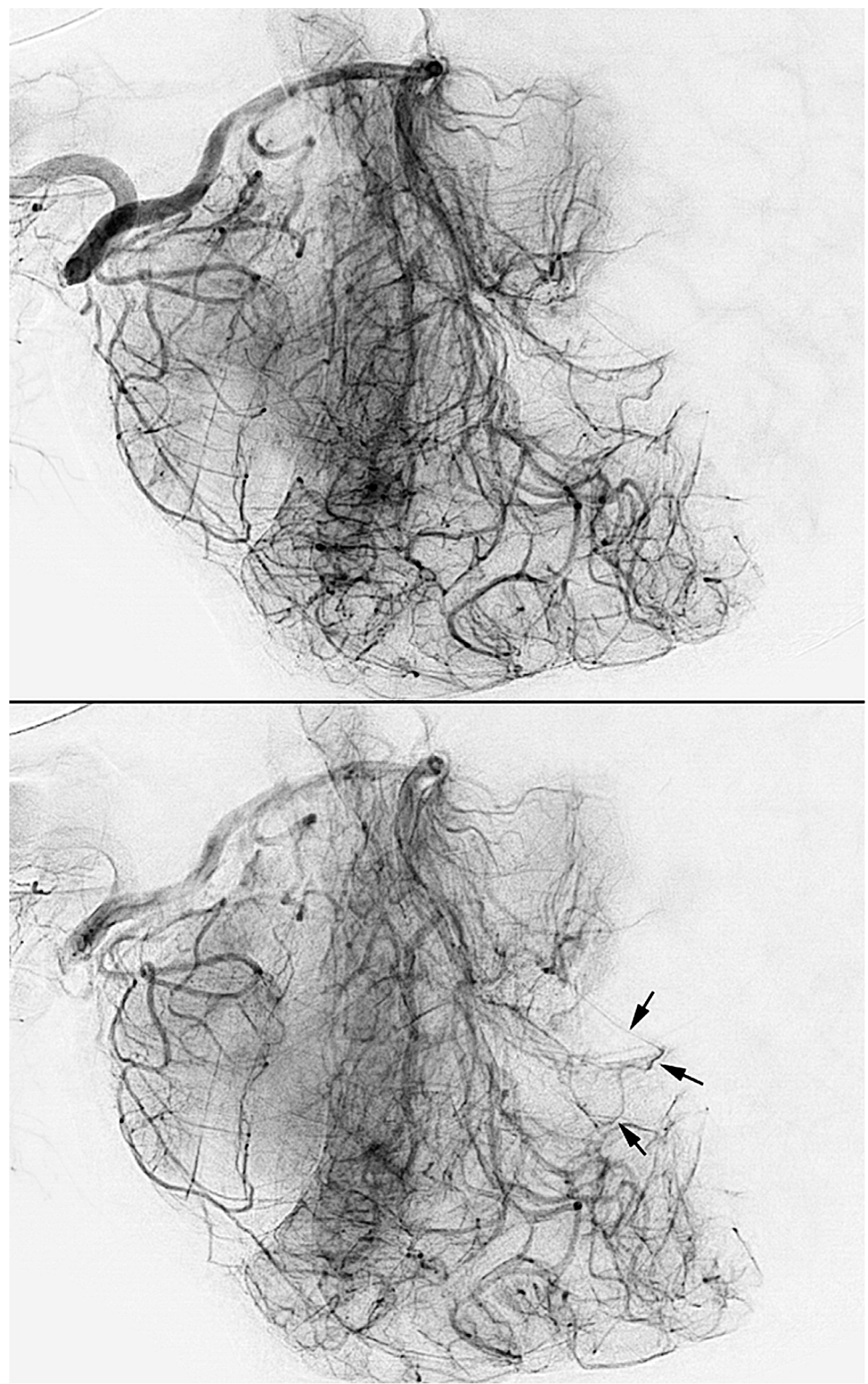

Fig. 3

A 32-year-old woman with a small arteriovenous malformation (AVM) located in the right parietooccipital fissure. Lateral vertebral magnified stereoscopic angiograms (late arterial phase) show a small AVM confidently fed by the small branch of the right parieto-occipital artery draining to the right medial atrial vein (arrows). This AVM was not detected by non-magnified, non-stereoscopic vertebral angiograms performed in the referring hospital. 


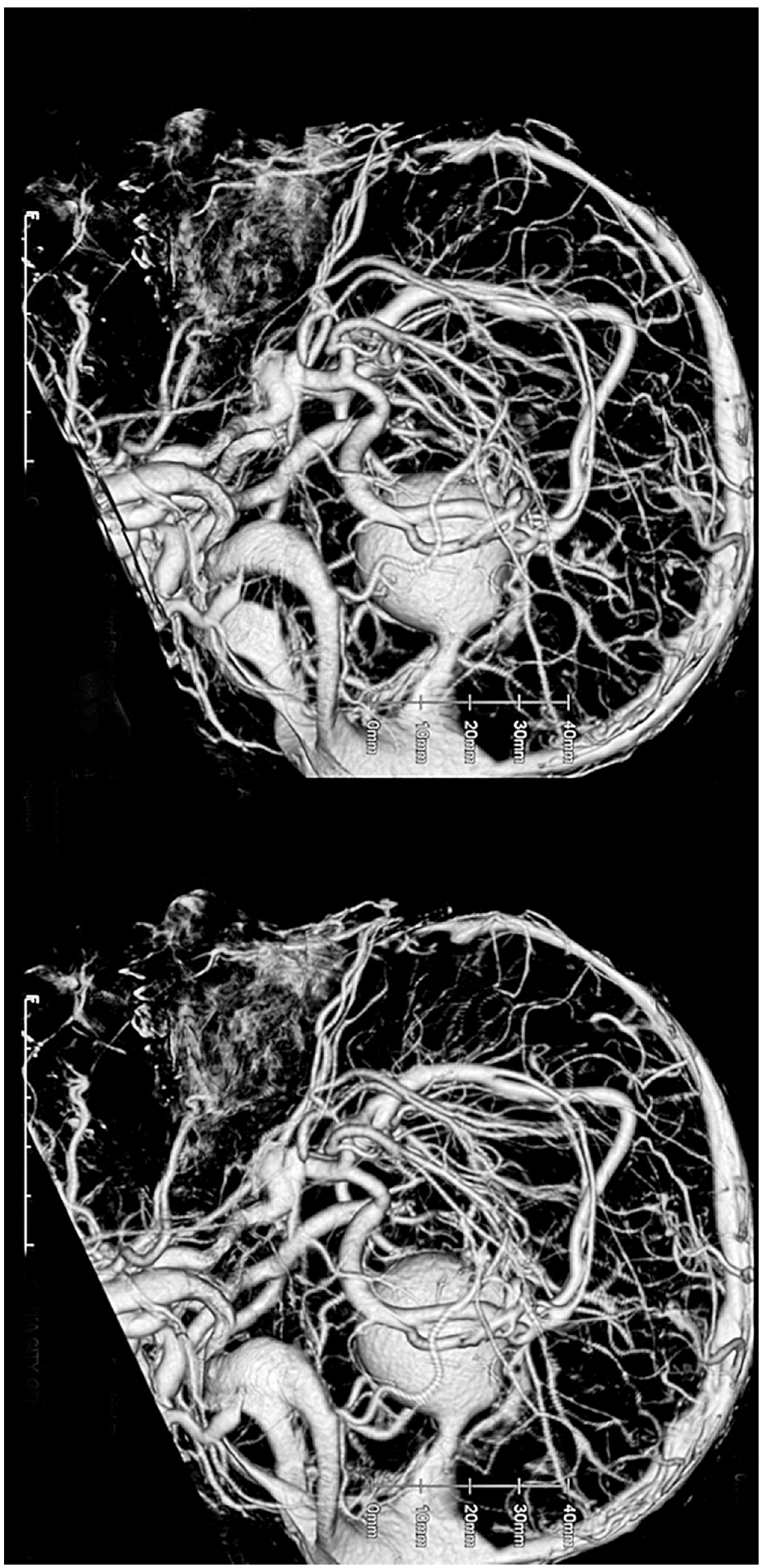

Fig. 4

A 6-month-old boy with choroidal type of vein of Galen aneurysmal malformation. A pair of stereoscopic CT angiograms show many choroidal feeders and perforating arteries converging to the large varix. Image interpretation is much enhanced by rotating these paired stereoscopic images by scrolling action of the mouse. 
した画像を 2 枚または 2 シリーズ撮像することは必 要である。理論的にはこの角度はある程度まで大き

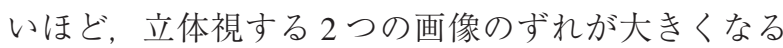
ので, 解剖学的な位置関係の認知は良くなる ${ }^{17)}$ 。通 常血管撮影では, biplaneの血管撮影装置を使用し ているので，正面・側面の両方の管球 -flat panel(ま たは image intensifier)を 6-12 度回転させ, 2 回撮像 する，film-screen angiographyでは，連続撮影を行う 為, 高速にフィルムを入れ替える film exchanger が必 要であった。

撮影画像をフィルムで見ていた時代は，シャウカ ステン Schaukasten に掛けた時相の揃ったペアーの フィルム画像を並べ立体視を行っていた，動脈相か ら静脈相まで見るためには，多数のフィルム画像を 順に並べる必要があり，長いシャウカステンを複数 利用したり，ボタン一つでシャウカステンを入れ替 えることができる読影装置を使うこともあった。し かし液晶モニター上で digital 画像を読影する機会が 増え，ステレオで画像を見るためには，高精細の 1 つまたは 2 つモニター上に対になる 2 画像を並べ て表示して立体視を行ない, マウスで paging を行な い動脈相から静脈相まで読影するようになっていっ た。フィルムによる脳血管撮影の頃は，立体視を するためにプリズムの入った眼鏡 (prismatic viewing glasses：この場合は, 右眼で右の画像を, 左眼で左 の画像を見ることになる)を使うこともあったが，こ のような眼鏡は使わずに裸眼で行う立体視では，右 眼で左側にある画像を見て, 左眼で右側にある画像 を見る crossed eye という方法(交差法)もしくは右眼 で右側の画像, 左眼で左側の画像を見る方法(平行 法)をとる.2つの画像の中間に立体感のある画像が 見え，この画像を読影する，道具を使わず，裸眼で 立体視が可能かどうかには個人差はあるが，少しト レーニングをすれば立体視が可能となる。

\section{立体脳・脊㟘道血管撮影と CT/MR angiography の立体視}

立体の血管撮影は, 3 次元的な解剖の描出に優 れ，重なり合った血管を分離し，より細い血管を描 出し，血管構築の理解を容易にする，立体視により 理論的に濃度分解能が 2 倍になり，造影剤濃度はよ り濃く観察できるため, 造影剤の濃度が下がる静脈 の描出, 春髄血管の描出, 僅かな血管の変化や腫瘍
のわずかな stainもより確信を持って診断可能とす $3^{12,24,25,29,30)}$. 3 次元的な血管解剖の理解によって間 違った読影を避けるという意味合いもある。CT/MR のない時代には血管撮影での血管の変位の読影が重 要であったが, 現在は血管のシフトや mass effect の 把握は CT/MR に任せ，上記の，血管の微細な解剖の 理解に立体撮影の役割が変わっている. DSA 装置の 空間分解能は 512 から 1024 さらには2048 マトリッ クスと向上したためにより細径の血管の観察ができ る様になった。また立体脳血管撮影をモニター上で 連続的に観察すると小さな動静脈シャントなどの局 所血行動態が良好に把握可能である。高空間分解能 と高濃度分解能に加え高時間分解能を備えた DSA 画 像を立体視することが，現時点における最も詳細な 局所脳血行動態の観察法であると言える。回転 3 次 元血管撮影でも，連続する 2 画像を立体視て読影す るのであれば，僅かな時相のずれ以外は，高空間分 解能と高濃度分解能を持つ画像を得ることができ る。しかし, 動脈相から静脈相まで, 時相の合った DSA 画像を立体視が可能という点で，2回の撮影に よる立体撮影法の方が優れている(Fig. 1-3).

この「立体視」は，脳血管撮影の読影だけに有用で あるだけでなく，CT/MRで作られた 3 次元画像を読 影するときにも同様の理由で有用であり, 単にモ二 ター上で1つの 3D 画像を動かして読影するだけでな く, ペアーの3D 画像をモニター上に表示させ立体視 し，それを回転させながら観察したほうが，3次元の 解剖情報は多い，脳動脈瘤のスクリーニングで行なっ たCT angiography や MR angiography の MIP 像を読影 する場合に, 左右に回転させた $2 つ の 3 D$ 画像をモ二 ター上に表示させ立体視した方が，はるかに血管解剖 の理解には有用であり，これに加え原画 source image を paging しながら細かい血管を適宜観察する(Fig. 4). 立体血管撮影法にはマイナス面もある。角度を変 えた同じシリーズの血管撮影を 2 回することによ り, 被爆線量, 造影剂量, 以前は記録用のフィルム 数が単純に倍になるという久点があった。しかし， それ以上の解剖学的な有用な情報を提供するため に，必要なシリーズに立体撮影を行なわれてきた。 最新機種の DSA 装置の被曝線量は flat panel detector を用いノイズを減らす画像化ソフトウェアーの開発 などで，以前と比較して画質はそのままで被曝線量 の $60 \%$ の低減が実現している ${ }^{31)}$ 。記録媒体はフィル 
ムではなくなり, digital dataの記録量は増えるが, 銀 フィルムほどの経費はかからなくなっている。

\section{結 語}

立体脳・脊髄血管撮影は, 1990 年代以前に確立し た技術であり，新しさは全くない。この古典的な 3 次元情報の表示方法はあまり臨床の場で使われない 時代となり, その有用性に接することのない若い世 代の医師も多く見られる。しかし, DSAの性能向上 に伴い従来よりも高精度の立体血管撮影が容易に得 ることができる。血管構築の理解に, CT/MRから 得られる非侵襲的な情報では不十分な場合には，力 テーテル血管撮影から得られる情報が重要となって くる. rotational angiography やその source image も有 用であるが, 古典的な立体撮影による血管情報は美 しく未だ色あせず有用である。

本論文の執筆にあたり久留米大学放射線科の安陪 等思先生にアドバイスを頂きました。この場を借り て深謝いたします。

著者に利益相反はありません.

\section{文 献}

1) Röntgen WC. Ueber eine neue Art von Strahlen (Vorkäufige Mittheilung.). In: Sitzungsberichte der physik. -med. Gesellschaft zu Würzburg 1985; 137: 132-141.

2) Dandy WE. Ventriculography following the injection of air into the cerebral ventricles. Ann Surg 1918; 68: 5-11.

3) Wolpert SM. Neuroradiology in Boston: historical beginnings. AJNR Am J Neuroradiol 1995; 16: 1093-1098.

4) Sicard JA, Forestier J. Méthode radiographique d'exploration de la cavité epidurale par le lipiodol. Rev Neurol (Paris) 1921; 28: 1264-1266.

5) Saito M, Kamikawa K, Yanagizawa H. Blood vessel visualization (arteriography; venography; angiography) in vivo. Am J Surg 1930; 10: 225-240.

6) Berberich J, Hirsch S. Die röntgenographische Darstellung der Arterien und Venen am lebenden Menschen. Klin Wchnschr 1923; 49: 2226-2228.

7) Moniz E. L'encéphalographie artérielle, son importance dans la localisation des tumeurs cérébrales. Rev Neurol (Paris) 1927; 34: 72-90.

8) Loman J, Myerson A. Visualization of the cerebral vessels by direct intracarotid injection of thorium dioxide (Thoratrast). AJR 1936; 35: 188-193.

9) Shimidzu K. Beiträge zur Arteriographie des Gehirns, einfache perkutane Methode. Arch klin Chir 1937; 188:
295-316.

10) Takahashi K. Die prekutane Arteriographie der Arteria vertebralis und ihrer Versorgungsgebiete. Arch Psychiat 1940; 111: 373-379.

11) Seldinger SI. Catheter replacement of the needle in percutaneous arteriography: a new technique. Acta radiol 1953; 39: 368-376.

12) Takahashi M, Tamakawa $Y$, Goto $K$, et al. Serial cerebral angiography in stereoscopic magnification. AJR Am J Roentgenol 1976; 126: 1211-1218.

13) Takahashi M, Ozawa Y. Routine biplane cerebral angiography with stereoscopic magnification. Radiology 1980; 136: 113-117.

14) Salamon G, Huang YP. Radiologic anatomy of the brain. Springer-Verlag, Berlin, Heidelberg, 1976.

15) Strother CM, Sackett JF, Crummy AB, et al. Intravenous video arteriography of the intracranial vasculature: early experience. AJNR Am J Neuroradiol 1981; 2: 215-218.

16) Christenson PC, Ovitt TW, Fisher HD, et al. Intravenous angiography using digital video subtraction: intravenous cervicocerebrovascular angiography. AJR Am J Roentgenol 1980; 135: 1145-1152.

17) Crummy AB, Stieghorst MF, Turski PA, et al. Digital subtraction angiography: current status and use of intraarterial injection. Radiology 1982; 145: 303-307.

18) Eggers FM, Price AC, Allen JH, et al. Neuroradiologic applications of intraarterial digital subtraction angiography. AJNR Am J Neuroradiol 1983; 4: 854-856.

19) Brant-Zawadzki M, Gould R, Norman D, et al. Digital subtraction cerebral angiography by intraarterial injection: comparison with conventional angiography. AJR Am J Roentgenol 1983; 140: 347-353.

20) Doppman J, Di Chiro G. Subtraction-angiography of spinal cord vascular malformations: report of a case. J Neurosurg 1965; 23: 440-443.

21) Di Chiro G, Wener L. Angiography of the spinal cord: a review of contemporary techniques and applications. $J$ Neurosurg 1973; 39: 1-29.

22) Djindjian R. Angiography of the spinal cord. Surg Neurol 1974; 2: 179-185.

23) Nelson PK, Setton A, Berenstein A. Vertebrospinal angiography in the evaluation of vertebral and spinal cord disease. Neuroimag Clin North Am 1996; 6: 589-605.

24) Vogelsang H, Dietz K. Stereoscopic magnification in spinal angiography. AJNR Am J Neuroradiol 1983; 4: 588-589.

25) Mokrohisky JF, Murtagh F, Paul RE, et al. Biplane stereoscopic cerebral angiography. Acta radiol 1956; 46: 262-272.

26) Fernstrom I, Lindblom K. Simultaneous stereoangiography. Acta radiol 1955; 44: 230-232.

27) Tobe T, Saito S, Toda N, et al. Simultaneous stereoroentogenography. Gunma J Med Sci 1966; 15: 23-31.

28) Doi K, Rossmann K, Duda EE. Application of longitudinal magnification effect to magnification stereoscopic angiography: a new method of cerebral angiography. Radiology 1977; 124: 395-401.

29) Worthington C, Peters TM, Ethier R, et al. Stereoscopic digital subtraction angiography in neuroradiologic assessment. 
AJNR 1985; 6: 802-808.

30) Doi K, Duda EE. Detectability of depth information by use of magnification stereoscopic technique in cerebral angiography. Radiology 1983; 146: 91-95.
31) Söderman M, Mauti M, Boon S, et al. Radiation dose in neuroangiography using image noise reduction technology: a population study based on 614 patients. Neuroradiology 2013; 55: 1365-1372.

\section{要 旨}

JNET 9:5-15, 2015

中枢神経系の血管病変の安全・確実な外科的治療や血管内治療に詳細な血管解剖の理解は必須である，そのような 解剖の画像データは低侵襲な CT や MR で得られるようになり，今日では診断の第一選択になっている，カテーテ ル血管撮影には，検査自体の持つ避けることのできない種々の合併症の可能性があるが, 今でも多くの症例に扔 いて重要な診断手段である。著者は中枢神経系の血管系の画像診断, 特に CT や MR の 3 次元再構成画像に加え力 テーテル血管撮影による画像診断に扔ける立体視(立体血管撮影)の役割の概説を行った。 